\title{
Inducible chitinolytic system of Aspergillus fumigatus
}

\author{
Gemma M. Escott, Veronica M. Hearn and David J. Adams
}

Department of

Microbiology, University of Leeds, Leeds LS2 9JT, UK
Author for correspondence: David J. Adams. Tel: +44 113233 5602. Fax: +441132335638. e-mail: d.j.adams@leeds.ac.uk

\begin{abstract}
Incubation of Aspergillus fumigatus NCPF 2140 in growth medium containing $1 \%$ chitin as sole carbon source led to induction of specific extracellular chitinolytic activity of $1.5 \mu \mathrm{mol}$ GICNAc released $\operatorname{~min}^{-1}$ (mg protein) ${ }^{-1}$. The effect was repressed by the inclusion of GIcNAc in the medium, indicating regulation by a negative feedback mechanism. Extracellular chitinase activity was inhibited by allosamidin $\left(I_{50} 0.12 \mu \mathrm{M}\right)$. Multiple chitinolytic enzymes were detected on zymograms of extracellular preparations; levels of individual enzymes induced were dependent upon whether cells were incubated with purified colloidal chitin or a crude preparation of crystalline chitin. A major, inducible, $45 \mathrm{kDa}$ chitinase was purified using ammonium sulphate precipitation, chitin affinity chromatography and a novel procedure involving the electroelution of the enzyme from a substrate gel containing glycol chitin. The enzyme is a glycoprotein with endochitinase activity.
\end{abstract}

Keywords: Aspergillus fumigatus, extracellular chitinase, enzyme induction, glycoprotein

\section{INTRODUCTION}

Chitin, the linear homopolymer of $\mathrm{N}$-acetylglucosamine (GlcNAc), is an important structural component of the crustacean integument, insect exoskeleton and fungal cell wall. The abundance of this polysaccharide in nature is matched by the wide range of organisms that produce chitinolytic enzymes. Plants produce chitinases and other lytic enzymes with roles in defence against fungal pathogens, while bacteria and other microorganisms secrete chitinases that appear to have roles in pathogenesis and/or nutrition (Gooday, 1990; Flach et al., 1992; Sahai \& Manocha, 1993; Graham \& Sticklen, 1994; Gooday, 1996). Chitinases with nutritional roles release more readily accessible oligomers of GlcNAc from insoluble, crystalline chitin in the environment. Organisms that contain structural chitin produce chitinases with roles during morphogenesis. For example, insect chitinases appear to have crucial roles during ecdysis (Flach et al., 1992) while fungal chitinases have roles during cell separation in yeasts, and are thought to contribute to a number of morphogenetic processes in filamentous fungi including spore germi-

Abbreviations: GICNAC, $N$-acetylglucosamine; 4-MU-GICNAC, 4-methylumbelliferyl- $N$-acetyl- $\beta$-D-glucosaminide; 4-MU-(GICNAC) ${ }_{2}$, 4-methylumbelliferyl- $\beta$-D- $N, N^{\prime}$-diacetylchitobioside; 4-MU-(GICNAC) ${ }_{3}, 4$-methylumbelliferyl- $\beta$-D- $N, N^{\prime}, N^{\prime \prime}$-triacetylchitotrioside. nation, side branch formation and autolysis (Gooday et al., 1992).

Aspergillus fumigatus is a ubiquitous saprophyte and an important opportunistic fungal pathogen of humans (Cohen, 1991; Barnes \& Denning, 1993; Campbell, 1994; Lewis et al., 1994). A. fumigatus is an interesting example of an organism that appears to produce chitinases with both morphogenetic and nutritional roles. A range of intracellular chitinolytic enzymes and, in particular, chitinases closely associated with cell wall fractions, are thought to have roles during morphogenesis (Hearn et al., 1996, 1997) while A. fumigatus represents one of the most abundant known sources of extracellular chitinase (Monreal \& Reese, 1969). This would imply that the fungus secretes large quantities of chitinase through a cell wall containing chitin. Currently, the mechanism that enables secretion of chitinase without digestion of the fungal wall is not understood. Similarly, although chitin has been shown to induce the release of chitinases by $A$. fumigatus and a number of other eukaryotes and prokaryotes (Monreal \& Reese, 1969; Flach et al., 1992; Sahai \& Manocha, 1993; Graham \& Sticklen, 1994; Adams \& Escott, 1997) there is a paucity of information concerning the mechanism that enables fungi, bacteria and higher plants to detect chitin polymers in the environment. A. fumigatus is an ideal model for the investigation of these phenomena and the aim of the current study was to characterize 
more fully the inducible chitinolytic system of this organism.

\section{METHODS}

Chemicals. Unless stated otherwise, all chemicals and reagents were purchased from either Merck (Analar grade) or Sigma-Aldrich. Radiochemicals were supplied by Amersham International. Allosamidin was kindly provided by Lilly Research Laboratories.

Organisms and culture conditions. Spore suspensions of $A$. fumigatus NCPF 2140 in $0 \cdot 1 \%$ Tween 80 obtained from $2-3 \mathrm{~d}$ cultures on Sabouraud's agar plates were used to inoculate flasks containing a volume of Vogel's $\mathrm{N}$ medium corresponding to one-fifth of the total capacity of the flask (Vogel, 1964) to a final concentration of $1 \times 10^{6}$ spores $\mathrm{ml}^{-1}$. Cultures were supplemented with either sucrose or $1 \%$ chitin in the presence or absence of $0.5 \%$ GlcNAc. Two chitin preparations were used: commercially available crystalline chitin isolated from crab shells (Sigma) or colloidal chitin prepared as described below. Cultures were incubated in an orbital incubator at $37^{\circ} \mathrm{C}$ and 200 r.p.m.

Synthesis of colloidal chitin. Colloidal chitin was synthesized by the acetylation of chitosan according to the method of Molano et al. (1977). Following homogenization, the chitin was filtered, washed and ball-milled as described by Dickinson et al. (1989). Chitin was resuspended in an appropriate volume and buffer according to its subsequent use.

Protein estimation. Protein concentration was determined using the method of Bradford (1976).

Chitinase assay. Chitinase was assayed using the method of Dickinson et al. (1989) with the following modifications. Reaction mixtures contained tritiated chitin suspension [60 $\mathrm{\mu l}$; $2.6 \mathrm{mg} \mathrm{ml}^{-1}, 70 \mathrm{kBq}$ (mg chitin $\left.)^{-1}\right], 50 \mathrm{mM}$ Bis Tris/HCl, pH 6.5 (assay buffer), and enzyme preparation (total volume $180 \mu \mathrm{l})$ and were incubated at $37^{\circ} \mathrm{C}$ in a shaking water bath (160 r.p.m.) for 1 h. The reaction was stopped by the addition of $180 \mu \mathrm{l} 10 \%$ trichloroacetic acid. All assays were performed at least in triplicate. Variation between replicates was never greater than $15 \%$.

Glycol chitin zymograms. Glycol chitin was synthesized as described by Trudel \& Asselin (1989) and incorporated into polyacrylamide gels using the method of St Leger et al. (1993) with the following modifications. Polyacrylamide separating gels $(12 \%)$ were used with stacking gels of $4.5 \%$ polyacrylamide; both contained $0.5 \%$ SDS. Samples were boiled for $3 \mathrm{~min}$ in a $1: 1$ dilution with boiling mix [ $10 \%$ stacking gel buffer $(0.5 \%$ SDS, $0.5 \mathrm{M}$ Tris/HCl, $\mathrm{pH} 6 \cdot 8), 2 \%$ SDS, $10 \%$, $\mathrm{v} / \mathrm{v}$, glycerol, $0.005 \%$ bromophenol blue]. Low-molecularmass protein markers (Pharmacia Biotech) were used to calibrate the gel. Electrophoresis was carried out at $30 \mathrm{~mA}$ for approximately $3.5 \mathrm{~h}$ using Hoeffer SE 600 electrophoresis apparatus. After SDS-PAGE, molecular mass markers were trimmed off and placed in fixative (methanol/water/acetic acid, $5: 5: 1$, by vol.) and protein bands were visualized by silver staining as described by Hitchcock et al. (1989). Chitinolytic activity in the remainder of the gel was detected as described by Escott \& Adams (1995).

Purification of $\mathbf{4 5} \mathbf{k D a}$ chitinase. Proteins were precipitated from culture filtrate $(7 \mathrm{~d}$ incubation of $A$. fumigatus NCPF 2140 in Vogel's $\mathrm{N}$ medium with $1 \%$ crystalline chitin as the sole carbon source) using $\left(\mathrm{NH}_{4}\right)_{2} \mathrm{SO}_{4}(60 \%$ saturation). Insoluble material was pelleted by centrifugation, resuspended in $50 \mathrm{mM}$ Bis Tris/ $\mathrm{HCl}, \mathrm{pH} 6.5$ and dialysed against the same buffer overnight at $4{ }^{\circ} \mathrm{C}$ to give a final volume of $10-20 \mathrm{ml}$ (8-15 mg protein). The dialysate was subjected to chitin affinity chromatography essentially as described by Mellor $e t$ al. (1994) but with the following modifications: the chitin suspension comprised $17 \mathrm{mg}$ (dry wt) colloidal chitin $\mathrm{ml}^{-1}$; the column was eluted against gravity at a flow rate of not more than $1 \mathrm{ml} \mathrm{min}-1$ and bound protein was eluted using $80 \mathrm{mM}$ acetic acid ( $25 \mathrm{ml} ; 2 \mathrm{ml}$ fractions).

Electrophoresis and electroelution. Proteins eluted from the chitin affinity matrix were electrophoresed on polyacrylamide gels containing glycol chitin (15 tracks, approx. $120 \mu$ per track) and chitinolytic activity detected essentially as described by Escott \& Adams (1995), except that the gel was incubated in $100 \mathrm{mM}$ sodium acetate, $\mathrm{pH} 4 \cdot 8$, at $30^{\circ} \mathrm{C}$ for only $2 \mathrm{~h}$. When the gel was illuminated with UV light, a zone of hydrolysis corresponding to the $45 \mathrm{kDa}$ chitinase was identified readily and excised from the gel using a scalpel. Protein was eluted from the gel by the method of Findlay et al. (1989) with the following modifications. The strip of gel was placed in a dialysis tubing bag containing electroelution buffer ( $50 \mathrm{mM}$ Tris/acetate, $\mathrm{pH} 7 \cdot 8,0 \cdot 1 \%$ SDS), excess buffer was squeezed from the bag and the bag was sealed and placed on the platform of an electrophoresis tank (GNA-200; Pharmacia Biotech) filled with electroelution buffer. Electrophoresis was performed overnight at room temperature and $50 \mathrm{~mA}$. The gel slice was removed from the bag, which was resealed and the contents dialysed overnight at $4{ }^{\circ} \mathrm{C}$ against three changes of $50 \mathrm{mM}$ Bis Tris $/ \mathrm{HCl}, \mathrm{pH} 6 \cdot 5$, prior to concentration using Centricon 10 devices according to the manufacturer's instructions (Amicon). The presence in the dialysate of a protein of $45 \mathrm{kDa}$ was confirmed following SDS-PAGE using the PhastSystem (Pharmacia Biotech) and silver staining of gels, although low-molecular-mass breakdown products were frequently detected following electroelution.

Protein sequencing. The electroeluted $45 \mathrm{kDa}$ chitinase was electrophoresed using SDS-PAGE under non-reducing conditions as described above for glycol chitin zymograms except that glycol chitin was omitted from gels $(1.5 \mu \mathrm{g}$ protein per lane). The gel was blotted using semi-dry blotting apparatus (Novoblot; Pharmacia Biotech) with CAPS transfer buffer (1 mM CAPS, $20 \%$ methanol, pH 11). The transferred protein was visualized by staining with sulphorhodamine $\mathrm{B}(0.005 \%$, in $30 \%$ methanol, $0 \cdot 2 \%$ acetic acid) for at least 2 min before rinsing briefly in distilled water and air drying. The sections of blot containing the $45 \mathrm{kDa}$ chitinase were excised and stored at $-20{ }^{\circ} \mathrm{C}$ prior to sequencing. The $\mathrm{N}$-terminus of the $45 \mathrm{kDa}$ chitinase was sequenced using automated solid-phase microsequencing (kindly performed by Dr A. Moir, University of Sheffield, UK).

Overlay gels incorporating 4-methylumbelliferylchitooligomer substrates. SDS-PAGE was performed as described above for glycol chitin zymograms except that glycol chitin was omitted from the separating gel and MiniProtean II gel electrophoresis apparatus (Bio-Rad) was used. Samples were prepared in non-reducing boiling mix and electrophoresed at $200 \mathrm{~V}$ for approximately $45 \mathrm{~min}$. Molecular mass markers were trimmed from the gel and placed in fixative. The remainder of the gel was incubated in casein buffer (Escott \& Adams, 1995). The gel was incubated for

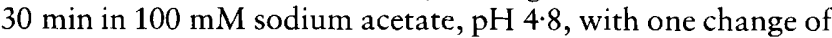
buffer and placed onto a glass plate for support. The overlay gel was as described by Pan et al. (1991) except that instead of glycol chitin, 4-methylumbelliferyl- $N$-acetyl- $\beta$-D-glucosaminide (4-MU-GlcNAc), 4-methylumbelliferyl- $\beta$-D- $N, N^{\prime}$ - 
diacetylchitobioside [4-MU-(GlcNAc $)_{2}$ ] or 4-methylumbelliferyl- $\beta$-D-N, $N^{\prime}, N^{\prime \prime}$-triacetylchitotrioside $\left[4-\mathrm{MU}-(\mathrm{GlcNAc})_{3}\right]$ $(0.03 \%)$ was used as substrate (Tronsmo \& Harman, 1993). Overlay gels were allowed to polymerize at room temperature for at least $1.5 \mathrm{~h}$ and the gels were incubated together for $15 \mathrm{~min}$ at $37^{\circ} \mathrm{C}$ in a moist atmosphere. Illumination with UV identified fluorescent bands where enzyme activity had released 4-methylumbelliferone from the chitooligomer.

Detection of glycoproteins. The periodic acid-Schiff method was used to visualize glycoproteins following SDS-PAGE (Dewald et al., 1974). Glycoproteins stained pink on a clear background.

\section{RESULTS}

\section{Induction of extracellular chitinase}

Chitinase was detected in the culture filtrate $72 \mathrm{~h}$ after A. fumigatus was inoculated into Vogel's $\mathrm{N}$ medium containing $1 \%$ colloidal chitin as the sole carbon source (Fig. 1). Similar results were obtained when $1 \%$ crystalline chitin was used as the carbon source (data not shown). The presence of chitin in the growth medium prevented accurate determination of growth phase based on estimation of biomass. However, it was evident from microscopic examination of cultures that the initial secretion of chitinase coincided with the onset of stationary phase, while the highest levels of extracellular chitinase were detected with the onset of autolysis. A very high level of specific chitinase activity $[1.5 \mu \mathrm{mol}$ GlcNAc released $\min ^{-1}$ (mg protein) ${ }^{-1}$ ] was detected at this time. Under the conditions described, chitinase activity was not detected when sucrose was included in the culture medium; identical results were obtained in the presence or absence of chitin. However, chitinase activity was detected in a freeze-dried concentrate of

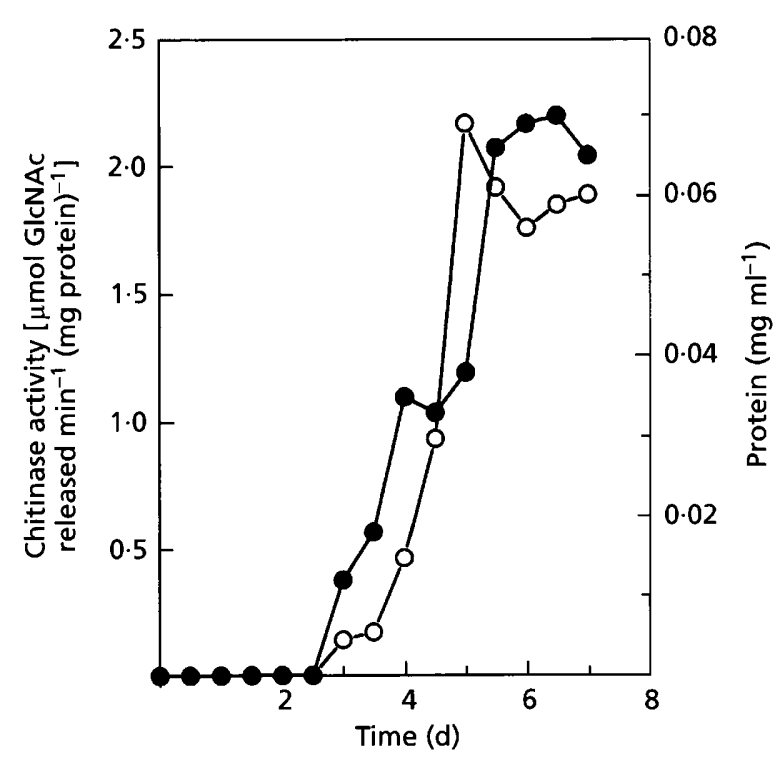

Fig. 1. Induction of extracellular chitinase of $A$. fumigatus cultured in a growth medium containing $1 \%$ colloidal chitin. 0 . Chitinase activity; 0 , total protein. The experiment was repeated with the same results. culture medium from A. fumigatus NCPF 2140 grown for $22 \mathrm{~h}$ in Vogel's $\mathrm{N}$ medium with sucrose as the sole carbon source (results not shown). This suggests that the constitutive secretion of chitinase occurs at such a low level that it is normally beyond the sensitivity of the assay method employed during the present study. When $0.5 \%$ GlcNAc was included in culture medium containing chitin as the sole carbon source, the level of extracellular chitinase produced was reduced markedly but the level of extracellular protein was unaffected (Table 1).

Crystalline and colloidal chitin appeared to induce a different range of chitinases (Fig. 2) although most of the chitinases induced by colloidal chitin were also induced by commercial chitin. There were also apparent differences in the relative activities of the enzymes induced by each chitin preparation. This was particularly noticeable for the triplet enzymes with molecular masses of approximately 32, 28 and $24 \mathrm{kDa}$. The apparent approximate molecular masses of the major extracellular chitinases induced by colloidal chitin were $110,69,45,32,28$ and $24 \mathrm{kDa}$ while those induced by crystalline chitin were of approximate molecular masses $110,94,69,62,45,39,32,28,24$ and $20 \mathrm{kDa}$. These experiments were repeated several times with the same results. The instability of proteinase inhibitors such as PMSF made it difficult to determine whether any of the low-molecular-mass chitinases detected on zymograms were attributable to proteolysis of larger enzymes during lengthy incubations of up to $7 \mathrm{~d}$. However, when chitinases were isolated from A. fumigatus mycelia a range of enzymes of differing molecular mass, similar to that detected during the present study, was identified in the presence or absence of aspartate-, cysteine-, metalloor serine-proteinase inhibitors (Hearn et al., 1997), suggesting that proteolysis does not contribute to the wide range of enzymes detected in cellular and extracellular extracts. GlcNAc $(0.5 \%)$ did not seem to affect the range of chitinases induced by either crystalline or colloidal chitin; instead, the level of each chitinase induced by the chitin preparations was reduced in the presence of the monomer. When a commercial preparation of $N$-acetylglucosaminidase ( $3 \mu \mathrm{g}$ protein) was electrophoresed in a glycol chitin gel, no chitinolytic activity was detected.

The chitinolytic activity detected in culture filtrates was clearly attributable to extracellular chitinases, as the specific chitinase inhibitor allosamidin was a potent inhibitor of chitinolysis. Inhibition curves for extracellular chitinases induced by colloidal or commercial chitin indicated $\mathrm{IC}_{50}$ values of approximately $0.1 \mu \mathrm{M}$ (Fig. 3).

\section{Purification and characterization of an extracellular chitinase}

An extracellular $45 \mathrm{kDa}$ chitinase was purified by ammonium sulphate precipitation, chitin affinity chromatography and electroelution from a polyacrylamide gel containing glycol chitin. Analysis of the N- 
Table 1. Effect of GICNAC on the induction of extracellular chitinase following inclusion of chitin in the growth medium and incubation for 4 or $7 \mathrm{~d}$

The experiment was repeated with essentially the same result.

\begin{tabular}{|c|c|c|c|c|}
\hline \multirow{2}{*}{$\begin{array}{l}\text { Addition(s) to } \\
\text { growth medium }\end{array}$} & \multicolumn{2}{|c|}{$4 \mathrm{~d}$} & \multicolumn{2}{|c|}{$7 \mathrm{~d}$} \\
\hline & $\begin{array}{l}\text { Total protein } \\
\qquad\left(\mu \mathrm{g} \mathrm{ml}^{-1}\right)\end{array}$ & $\begin{array}{l}\text { Specific } \\
\text { chitinase } \\
\text { activity } \dagger\end{array}$ & $\begin{array}{l}\text { Total protein } \\
\quad\left(\mu \mathrm{g} \mathrm{ml}^{-1}\right)\end{array}$ & $\begin{array}{l}\text { Specific } \\
\text { chitinase } \\
\text { activity }\end{array}$ \\
\hline Colloidal chitin & 39 & $0 \cdot 200$ & 99 & $1 \cdot 251$ \\
\hline $\begin{array}{l}\text { Colloidal chitin, } \\
\text { GlcNAc }\end{array}$ & 59 & $0 \cdot 103$ & 107 & 0.452 \\
\hline $\begin{array}{l}\text { Commercial } \\
\text { chitin }\end{array}$ & 40 & 0.908 & 54 & $1 \cdot 296$ \\
\hline $\begin{array}{l}\text { Commercial } \\
\text { chitin, GlcNAc }\end{array}$ & 42 & 0.458 & 46 & $0 \cdot 509$ \\
\hline
\end{tabular}

*Vogel's N medium (Vogel, 1964) was used throughout. Colloidal or commercial chitin was used at $1 \%$. GlcNAc was used at $0 \cdot 5 \%$.

$\dagger \mu \mathrm{mol}$ GlcNAc released $\min ^{-1}(\mathrm{mg} \text { protein })^{-1}$.

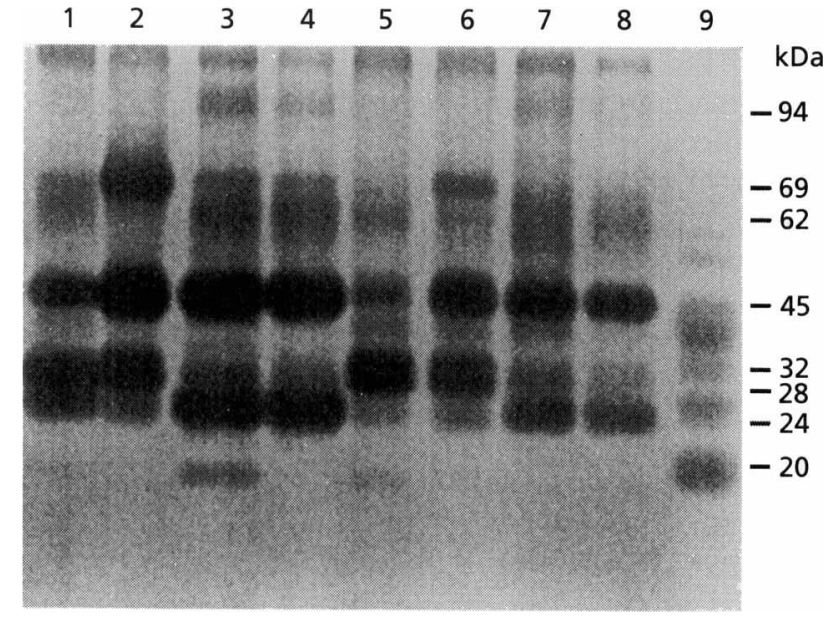

Fig. 2. Zymogram demonstrating induction of extracellular chitinases of $A$. fumigatus and the effect of GICNAC on induction. The culture medium was Vogel's $N$ medium supplemented with different chitin preparations $(1 \%)$. The polyacrylamide gel ( $12 \%$ acrylamide) incorporated glycol chitin as a substrate for chitinase; $1.25 \mu \mathrm{g}$ protein was used in lanes 1-8 and $3 \mu \mathrm{g}$ protein in lane 9 . Lanes: 1 and 2, colloidal chitin, harvested at $4 \mathrm{~d}$ and $7 \mathrm{~d}$, respectively; 3 and 4 , commercial chitin, harvested at $4 \mathrm{~d}$ and $7 \mathrm{~d}$, respectively; 5 and 6 , colloidal chitin and $0.5 \%$ GlcNAc harvested at $4 \mathrm{~d}$ and $7 \mathrm{~d}$, respectively; 7 and 8 , commercial chitin and $0.5 \%$ GlcNAc harvested at $4 \mathrm{~d}$ and $7 \mathrm{~d}$, respectively. Lane 9, Streptomyces griseus chitinase (Sigma).

terminus of this protein revealed homology with chitinases from other fungi and most notably with the enzymes from Coccidioides immitis, Trichoderma harzianum and Aphanocladium album (Fig. 4). PCR primers based on the sequence of the $\mathrm{N}$-terminus of the Aspergillus fumigatus chitinase and conserved residues

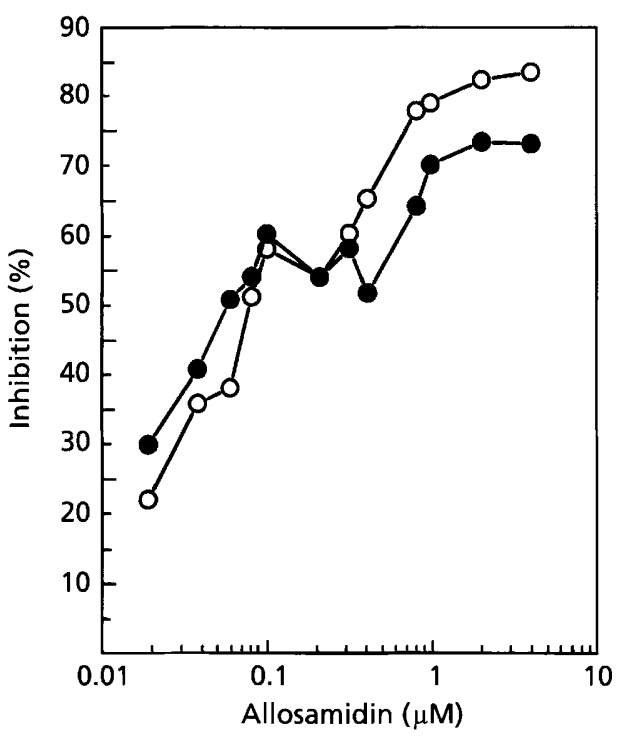

Fig. 3. Effect of allosamidin on extracellular chitinase induced by growth in medium containing colloidal (O) or crystalline (O) chitin as sole carbon source. The experiment was repeated with essentially the same result.

in fungal chitinases were used to amplify two fragments of approximately $450 \mathrm{bp}$ from $A$. fumigatus. The fragments have $>60 \%$ homology with the C. immitis cts1 gene (A. K. Jaques, G. M. Escott, R. Barton, C. A. Hitchcock \& D. J. Adams, unpublished).

When the purified $45 \mathrm{kDa}$ chitinase was electrophoresed in an SDS-polyacrylamide gel and the gel incubated with an overlay gel containing 4-MU-GlcNAc, 4-MU$(\mathrm{GlcNAc})_{2}$ or $4-\mathrm{MU}-(\mathrm{GlcNAc})_{3}$, the chitinase did not cleave 4-MU-GlcNAc (data not shown) but released 4- 


\begin{tabular}{|c|c|c|c|c|}
\hline & 15 & 16 & 31 & 46 \\
\hline 1. fumigatus & & & SSGYRSVVYF & VNWAIYGRN \\
\hline C. immitis & -MRFLIGALLTLQTL & VQASSMSSMPNYYPV & PEAPAEGGFRSVVYF & VNWAI YGRGHNPQDL \\
\hline T. harzianum & MLGELGKSVALLAAL & QATLISASPVTANDV & SVEKRASGYANAVYE & TNWGIYGRNFQPQNL \\
\hline A. album & MLSEVKKSIALVAAL & QAVTALATPISSE-A & GVEKRGSGFANAVYF & TNWGIYGRNEQPADL \\
\hline
\end{tabular}

Fig. 4. Homology between the $\mathrm{N}$-terminus of the $A$. fumigatus $45 \mathrm{kDa}$ chitinase and the $\mathrm{N}$-termini of chitinases from other fungi. Homology was identified by submitting the $A$. fumigatus sequence and all fungal chitinase protein sequences (24 sequences) currently lodged in GenBank to the Multiple Sequence Alignment facility of the BCM Search Launcher (Human Genome Center, Houston, TX, USA). The proteins showing the greatest homology with the $A$. fumigatus $\mathrm{N}$-terminus are shown here. GenBank accession numbers: Coccidioides immitis complement fixation antigenchitinase, U60807; Trichoderma harzianum ech42, X79381; Aphanocladium album chi1, P32470.

(a)

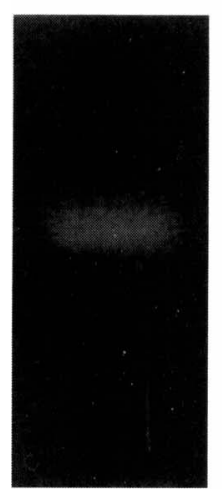

(b)

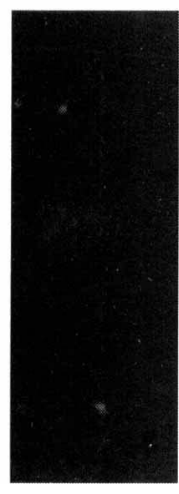

(c)

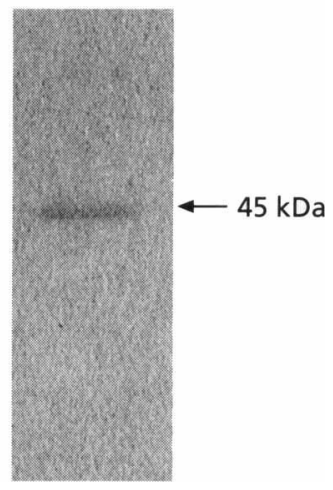

Fig. 5. Characterization of the $45 \mathrm{kDa}$ chitinase in polyacrylamide gels. Detection of chitinolytic activity in a polyacrylamide gel ( $12 \%$ acrylamide, containing $1.25 \mu \mathrm{g}$ protein per track) used an overlay gel of polyacrylamide containing (a) $4 \mathrm{MU}-(\mathrm{GICNAC})_{3}$, or (b) $4 \mathrm{MU}-(\mathrm{GICNAC})_{2}$ as substrate. The experiment was repeated twice with the same results. (c) Periodic acid-Schiff-stained polyacrylamide gel $(12 \%$ acrylamide, containing $2 \mu \mathrm{g}$ protein).

methylumbelliferone from 4-MU-(GlcNAc $)_{2}$ and 4-MU$(\mathrm{GlcNAc})_{3}$ (Fig. 5a, b). These results indicate that the $45 \mathrm{kDa}$ enzyme is an endochitinase; an exochitinase would cleave 4-MU-(GlcNAc) ${ }_{3}$ at the central $\beta, 1-4$ bond, yielding 4-MU-GlcNAc and chitobiose and, therefore, no fluorescent product would be produced. The enzyme also cleaved the longer chain chitooligomer substrate more readily (Fig. 5a, b), a phenomenon observed previously for other endochitinases (Cabib, 1987; Tronsmo et al., 1996). A single protein band corresponding to the band with endochitinase activity was detected when gels were silver stained (results not shown).

When ConA-Sepharose was used for lectin affinity chromatography, most of the extracellular chitinases adhered to the column matrix (results not shown), indicating that these enzymes are glycoproteins. Confirmation that the purified $45 \mathrm{kDa}$ chitinase is a glycoprotein was obtained by staining the chitinase in an SDS-polyacrylamide gel using the periodic acid-Schiff method (Fig. 5c).

\section{DISCUSSION}

Our results indicate clearly that under certain growth conditions, A. fumigatus secretes abundant quantities of chitinase and the array of extracellular chitinolytic enzymes detected appears to reflect the wide range of chitinases identified in intracellular, cell wall and cell surface preparations from this organism (Hearn et al., 1996, 1997). The application of a procedure we described previously for the purification of chitinase from Candida albicans (Mellor et al., 1994), combined with the electroelution of protein from a substrate gel containing glycol chitin, enabled the rapid purification of an extracellular chitinase from $A$. fumigatus. The enzyme is a glycoprotein with endochitinase activity. Determination of the $\mathrm{N}$-terminal sequence of this protein, coupled with the identification of regions of conserved sequence in chitinases from a range of organisms, has enabled us to design PCR primers which we have used for the identification of at least three chitinase genes in A. fumigatus (A. K. Jaques, G. M. Escott, R. Barton, C. A. Hitchcock \& D. J. Adams, unpublished). The results of the present study suggest that A. fumigatus contains several genes encoding chitinases. In the longer term, gene disruption experiments will allow us to determine precise roles for these enzymes. Fungal chitinases with roles during differentiation have been proposed as potential targets for antifungal agents. Comparison of the roles of A. fumigatus chitinases with those of chitinolytic enzymes produced by human cells (Overdijk \& Van Steijn, 1994; Escott \& Adams, 1995; Renkema et al., 1995) should enable a more thorough evaluation of the potential of fungal chitinases as targets for antifungal agents. If human chitinases are shown to have roles in host defence, it may be necessary to reconsider the suitability of fungal chitinases as drug targets. Instead, the identification of mechanisms that regulate the activity of microbial chitinases and other autolysins at the level of transcription or post-translational modification may unveil alternative, specific targets for novel antifungal drugs.

It is equally important that mechanisms regulating the induction and secretion of chitinases from $A$. fumigatus should be characterized more fully. A wide range of organisms including higher plants, bacteria and a number of fungi produce abundant quantities of chi- 
tinase in response to chitinous materials in the environment. However, it is not yet clear how these organisms detect the presence of the insoluble chitin polymer outside the cell. The induction of differing profiles of $A$. fumigatus chitinolytic enzymes by semisynthetic (colloidal) and crude (crab shell) chitin preparations is of particular interest. Thus, for example, a chitinase of apparent molecular mass $94 \mathrm{kDa}$ was induced when A. fumigatus was cultured in a medium containing colloidal chitin as the sole carbon source (Fig. 2). However, this enzyme was not detected when $A$. fumigatus was grown in a medium containing crystalline chitin. In addition, comparison of tracks 1 and 2 with tracks 3 and 4 of Fig. 2 indicates clearly that the levels of individual chitinases induced by one chitin preparation differed markedly from the levels of enzymes induced by the other. A similar effect was demonstrated for Aphanocladium album, which produced nine chitinases when grown with colloidal chitin as the sole carbon source, but only three chitinases when crystalline chitin was used as the carbon source (Studer et al., 1992). This work and the results obtained during the present study imply that Aphanocladium album and Aspergillus fumigatus can detect differing configurations of chitin and, perhaps, cross-linking of the polysaccharide to other polymers in the growth medium. Partial degradation of chitinous material in the environment, by low levels of chitinase secreted constitutively by Aspergillus fumigatus, will yield a range of oligomers which may stimulate transcription of chitinase genes by interacting with receptors in the fungal cell (Adams \& Escott, 1997). This induction mechanism would enable Aspergillus fumigatus to utilize a range of complex chitinous substrates while repression of chitinase secretion by GlcNAc prevents wasteful synthesis of the enzyme in the presence of abundant quantities of the ultimate product of chitin hydrolysis. Similar induction-repression mechanisms were identified in Trichoderma harzianum, where both glucose and GlcNAc repressed the synthesis of induced chitinase (Ulhoa \& Peberdy, 1991), and in Metarhizium anisopliae, where chitinase synthesis was repressed by the addition of alanine, a readily utilized nutrient source (St Leger et al., 1993). The extensive chitinolytic system of $A$. fumigatus provides an interesting model for further studies of chitinase induction and repression, phenomena that are important in plant defence, entomo- and myco-parasitism and the production of bacterial and fungal chitinases that enable biodegradation of chitin in the environment.

\section{ACKNOWLEDGEMENTS}

We gratefully acknowledge the financial support of the Medical Research Council and the Wellcome Trust and thank Lilly Research Laboratories for supplying allosamidin.

\section{REFERENCES}

Adams, D. J. \& Escott, G. M. (1997). Chitinases of fungal pathogens and human blood cells. In Fungal Cells in Biodefense Mechanism, pp. 233-238. Edited by M. Suzuki \& S. Suzuki. Tokyo: Saikon Publishing.
Barnes, A. J. \& Denning, D. W. (1993). Aspergilli - significance as pathogens. Rev Med Microbiol 4, 176-180.

Bradford, M. M. (1976). A rapid and sensitive method for the quantitation of microgram quantities of protein utilizing the principle of protein-dye binding. Anal Biochem 72, 248-254.

Cabib, E. (1987). The synthesis and degradation of chitin. Adv Enzymol 59, 59-101.

Campbell, C. K. (1994). Forms of aspergillosis. In The Genus Aspergillus, pp. 313-317. Edited by K. A. Powell, A. Renwick \& J. F. Peberdy. New York: Plenum.

Cohen, J. (1991). Clinical manifestations and management of aspergillosis in the compromised patient. In Fungal Infection in the Compromised Patient, pp. 117-152. Edited by D. W. Warnock and M. D. Richardson. Colchester: Wiley.

Dewald, B., Dulaney, J. T. \& Touster, O. (1974). Solubilisation and polyacrylamide gel electrophoresis of membrane enzymes with detergents. Methods Enzymol 32, 82-91.

Dickinson, K., Keer, V., Hitchcock, C. A. \& Adams, D. J. (1989). Chitinase activity from Candida albicans and its inhibition by allosamidin. J Gen Microbiol 135, 1417-1421.

Escott, G. M. \& Adams, D. J. (1995). Chitinase activity in human serum and leukocytes. Infect Immun 63, 4770-4773.

Findlay, J. B. C., Pappin, D. J. C. \& Keen, J. N. (1989). Automated solid-phase microsequencing. In Protein Sequencing. A Practical Approach, pp. 69-84. Edited by J. B. C. Findlay \& M. J. Geisow. Oxford: IRL Press.

Flach, J., Pilet, P. E. \& Jollès, P. (1992). What's new in chitinase research? Experientia 48, 701-716.

Gooday, G. W. (1990). The ecology of chitin degradation. Adv Microb Ecol 11, 387-430.

Gooday, G. W. (1996). Aggressive and defensive roles for chitinases. In Chitin Enzymology, vol. 2, pp. 125-134. Edited by R. A. A. Muzzarelli. Grottammare: Atec Edizione.

Gooday, G. W., Zhu, W.-Y. \& O'Donnell, R. W. (1992). What are the roles of chitinases in the growing fungus? FEMS Microbiol Lett 100, 387-392.

Graham, L. S. \& Sticklen, M. B. (1994). Plant chitinases. Can J Bot 72, 1057-1083.

Hearn, V. M., Escott, G. M., Evans, E. G. V. \& Adams, D. J. (1996). Chitinases of the cell surface and wall of Aspergillus fumigatus. In Chitin Enzymology, vol. 2, pp. 261-272. Edited by R. A. A. Muzzarelli. Grottammare: Atec Edizione.

Hearn, V. M., Escott, G. M., Evans, E. G. V. \& Adams, D. J. (1997). Intracellular and wall-associated chitinases of Aspergillus fumigatus. In Fungal Cells in Biodefense Mechanism, pp. 247-252. Edited by M. Suzuki \& S. Suzuki. Tokyo: Saikon Publishing.

Hitchcock, C. A., Dickinson, K., Brown, S. B., Evans, E. G. V. \& Adams, D. J. (1989). Purification and properties of cytochrome P450-dependent $14 \alpha$-sterol demethylase from Candida albicans. Biochem J 263, 573-579.

Lewis, C. W., Anderson, J. G. \& Smith, J. E. (1994). Health-related aspects of the genus Aspergillus. In Aspergillus, pp. 219-261. Edited by J. E. Smith. New York: Plenum.

Mellor, K. J., Nicholas, R. O. \& Adams, D. J. (1994). Purification and characterisation of chitinase from Candida albicans. FEMS Microbiol Lett 119, 111-118.

Molano, J., Duran, A. \& Cabib, E. (1977). A rapid and sensitive assay for chitinase using tritiated chitin. Anal Biochem 83, $648-656$. 
Monreal, J. \& Reese, E. T. (1969). The chitinase of Serratia marcescens. Can J Microbiol 15, 689-696.

Overdijk, B. \& Van Steijn, G. J. (1994). Human serum contains a chitinase: identification of an enzyme, formerly described as 4methylumbelliferyl-tetra- $N$-acetylchitotetraoside hydrolase (MU-TACT hydrolase). Glycobiology 4, 797-803.

Pan, S. Q., Ye, X. S. \& Kuc, J. (1991). A technique for detection of chitinase, $\beta$-1,3-glucanase and protein patterns after a single separation using polyacrylamide gel electrophoresis or isoelectric focusing. Phytopathology 81, 970-974.

Renkema, G. H., Boot, R. G., Muijsers, A. O., Donker-Koopman, W. E. \& Aerts, J. M. F. G. (1995). Purification and characterization of human chitotriosidase, a novel member of the chitinase family of proteins. J Biol Chem 270, 2198-2202.

Sahai, A. S. \& Manocha, M. S. (1993). Chitinases of fungi and plants: their involvement in morphogenesis and host-parasite interaction. FEMS Microbiol Rev 11, 317-338.

St Leger, R. J., Staples, R. C. \& Roberts, D. W. (1993). Entomopathogenic isolates of Metarhizium anisopliae, Beauveria bassiana and Aspergillus flavus produce multiple extracellular chitinase isoenzymes. J Invertebr Pathol 61, 81-84.
Studer, M., Flück, K. \& Zimmermanm, W. (1992). Production of chitinases by Aphanocladium album grown on crystalline and colloidal chitin. FEMS Microbiol Lett 99, 213-216.

Tronsmo, A. \& Harman, G. E. (1993). Detection and quantification of $N$-acetyl- $\beta$-D-glucosaminidase, chitobiosidase and endochitinase in solutions and on gels. Anal Biochem 208, 74-79.

Tronsmo, A., Hjeljord, L., Klemsdal, S. S., Vårum, K. M., Nordtveit Hjerde, R. \& Harman, G. E. (1996). Chitinolytic enzymes from the biocontrol agent Trichoderma harzianum. In Chitin Enzymology, vol. 2, pp. 235-244. Edited by R. A. A. Muzzarelli. Grottammare: Atec Edizione.

Trudel, J. \& Asselin, A. (1989). Detection of chitinase activity after polyacrylamide gel electrophoresis. Anal Biochem 178, 362-366.

Ulhoa, C. J. \& Peberdy, J. F. (1991). Regulation of chitinase synthesis in Trichoderma harzianum. I Gen Microbiol 137, 2163-2169.

Vogel, H. J. (1964). Distribution of lysine pathways among fungi: evolutionary implications. Am Nat 98, 435-446.

Received 3 December 1997; revised 4 February 1998; accepted 12 February 1998. 